\title{
Başkurtlarda Eski Türk Takvimi ve Nevruz Bayramının Kutlanması*
}

\author{
Ahat Salihov **
}

Öz

Diğer Türk halklarında olduğu gibi Başkurtlarda da eski takvime göre yılbaşı bayramı olarak kutlanan Nevruz eskiden beri en önemli bayramlardan biri olmuştur. Nevruz Bayramı on iki hayvanlı Türk takvimine göre Mart ayında icra edilmiştir. Başkurt folklorunda bu bayram için söylenilen çeşitli şiirler bulunmaktadır. Bu şiirlerde Nevruz bayramı sırasında insanlar birbirlerine yılın iyi olmasını, buğdayların iyi yetişmesini söylemişlerdir. Başkurtlarda Nevruz bayramının ekin ekildikten sonra yapılan Sabantoy bayramına benzeyen bazı tarafları bulunmaktadır. Her iki bayram baharda yapılır, bol bol millî yemekler hazırlanır, o yılki hasadın iyi olması dilenir. Bahar gelince doğa yeşillenir. Nevruz da bununla bağlantılıdır. Türk halkındaki Hızır kelimesi, Arapçada yeşil anlamına gelmektedir. Hızır miti, Başkurtlarda da çok yaygındır. Nevruzda çeşitli geleneksel halk oyunları oynamışlar, bayram sırasında yılın nasıl olacağını yorumlamışlardır.

Başkurt kültürünün bir parçası hâline gelen bu bayram geçtiğimiz asırda çeşitli nedenlerle unutulmaya yüz tutmuştur. 1990 yılından itibaren tekrar kutlanmaya başlanmış. Ancak, Sabantoya nazaran Nevruz daha küçük çapta kutlanmaktadır.

\section{Anahtar Kelimeler}

Türk kültürü, Nevruz, on iki hayvanlı Türk takvimi, Başkurtlar, millî bayramlar.

Geliş Tarihi: 07 Kasım 2016 - Kabul Tarihi: 23 Mayıs 2018

Bu makaleyi şu şekilde kaynak gösterebilirsiniz:

Salihov, Ahat (2019). "Başkurtlarda Eski Türk Takvimi ve Nevruz Bayramının Kutlanması".

bilig - Türk Dünyası Sosyal Bilimler Dergisi 88: 189-203.

** Ph.D., Rusya Bilimler Akademisi Ufa Federal Araştırma Merkezi Tarih, Dil ve Edebiyat Enstitüsü, Doğu Elyazmalar Bölümü - Ufa/Rusya ORCID ID: https://orcid.org/0000-0002-7994-4711

ahatsalihov@mail.ru 


\section{Giriş}

Türk halklarında, eski zamanlarda on iki hayvanlı takvim kullanılmıştır. Bu takvime göre yılbaşı günümüz takvimine göre 21 Martta başlamıştır. Bu takvimin ortaya çıkışını anlatan eski bir rivayet, 11. asırda yaşayan Mahmud Kaşgarlı'nın Divanü Lügati't-Türk adlı eserinde kaydedilmiştir (Atalay 1992: 344-345, Turan 2004).

Türklerde yılbaşı bayramı olarak kutlanılan Nevruz bayramı da bu takvimdeki yılbaşı tarihi ile aynı zamanda icra edilmektedir. Diğer Türk halklarındaki gibi Başkurtlarda da eski Türk takvimine göre yılbaşı bayramı olarak Nevruz en önemli bayramların biri olmuştur. Başkurt Halk edebiyatında da Nevruz ile ilgili eserler mevcuttur (Süleymanov, Soltangereyeva 1995: 191-193).

Nevruz, Başkurtlarda çok eski zamanlardan beri kutlanan bir bayramdır. Başkurt kültürünün bir parçası olan bu bayram geçtiğimiz asırda çeşitli nedenlerle unutulmaya yüz tutmuştur. Bunun nedenlerinden biri olarak Rusyada 1917 yılındaki devrimin etkileri gösterilebilir. Çünkü bu devrimden sonra toplum içinde ortaya çıkan sosyal değişmeler sebebiyle eskimiş olarak kabul edilen pek çok gelenek, dinî bayramlar, Arap harfleriyle yazılmış eserler kaldırılmaya başlamıştır. Nevruz ile bazı benzer yönleri olan Sabantoy bayramını ise 1921 yılından itibaren "umumi halk spor ve hizmet bayramı" adıyla resmî olarak kutlamaya başlatmışlardır (Valişin vd. 2011: 12). Böylece Doğu medeniyetleriyle çok ilişkili olan Nevruz resmi kutlamalar dışında kalmasından dolayı unutulmaya yüz tutmuştur. Ancak 20. asrın sonunda ortaya çıkan sosyal değişiklikler, bu bayramın yeniden yaşatılmasına imkân vermiştir. 1990 yılından itibaren de Başkurdistan'da tekrar kutlanmaya başlanmıştır (Tuhvatullin, Başkortostan Gazetesi, 21.04.1990).

Bu bayram ile ilgili Başkurtların tarihî belgelerinde ve halk edebiyatı örneklerinde birçok bilgi bulunmaktadır. Pek çok bilim adamı da bu konuda araştırma yapmıştır. Türkiye'de, Başkurtların Nevruz kutlaması ile ilgili halk edebiyatı örnekleri ve onunla ilgili yazılar Başkurt folklor araştırmacısı Ahmet Süleymanov tarafından kaleme alınmıştır (Süleymanov 2000). Ancak Başkurtlarda Nevruz bayramının özellikleri ile ilgili olarak yeni bilgilerin bir araya getirildiği araştırmaların yapılmasına ve bunların yazıya geçirilmesine ihtiyaç duyulmaktadır. Bu konuyu inceleyen bilim adamları bayramın tarihi akışı hakkında malumatın oldukça az olduğunu bildirmektedir (Yazıcı Ersoy 2007: 262, Süleymanov 1995: 181). 


\section{On İki Hayvanlı Türk Takvimi}

Türk halklarının eski zamanlardan başlayıp bazılarının orta çağlara, bir kısmının ise günümüze kadar kullandıkları On iki hayvanlı takvimi bulunmaktadır. Türklerin kullandığı takvimler hakkında çeşitli kaynaklarda bilgiler mevcuttur ve yetmiş sene önce Türkiyeli bilim adamı Osman Turan tarafından kapsamlı bir araştırma yapılmışır. Geçen asrın ilk yarısının sonunda gerçekleştirilen bu inceleme günümüzde de bu konuda yapılan en önemli araştırmadır. Nevruz Bayramı'nın eski on iki hayvanlı Türk takvimi ile ilişkili olduğunu belirtmek gerekir (Turan 2004: 43).

Dünyadaki tüm halklar tarih boyunca çeşitli takvimler kullanmışlardır. Bugün bile birçok devlet ve halk değişik zaman hesabı kullanmaktadır. Günümüzde ise şu anda kullandığımız Gregoryen takvimi en yaygın olanıdır.

Türkler tarihte çeşitli takvimler kullanmışlardır. Eski el yazmalarında ve kitaplarda, yazarlar tarihleri o dönemlerde kullanılan birkaç takvime göre belirlemişlerdir. Örneğin, Tacettin Yalçıgul El-Başkurdi (1768-1836) meşhur Risale-yi Azize kitabında: "Hicri 1121 yılında, Yılkı (at) yılında tamam eyledim" demiştir (Tacettin bin Yalçıgul 1908: 4). Burada da görüldüğü gibi kitabın tamamlanması, hem Hicrî hem de on iki hayvanlı takvime göre tarihlendirilmiştir. Türklerin ve Asya'daki bazı halkların da böyle bir takvimi kullandığı bilinmektedir.

Kaşgarlı Mahmut'un, Divanü Lügati't-Türk (XI. yüzyıl) adlı eserinde eski Türk takvimi hakkında pek çok bilgi verilmiş ve yıl hesabının ortaya çıkışı şöyle anlatılmıştır:

Türkler on iki çeşit hayvanın adını on iki yıla ad olarak vermişlerdir. Çocukların yaşlarını, savaş tarihlerini ve daha pek çok şeyi bu yılların dönmesi ile hesap ederlerdi. Bunun hikâyesi ise şöyledir:

Türk hakanlarından biri geçmişteki bir savaşı öğrenmek ister. O savaşın yapıldığı yılı hatırlamakta yanılmaları üzerine hakan ulusuyla müşavere yapar ve kurultayda "Biz bu tarihte nasıl yanıldıysak bizden sonra gelecek olanlar da yanılacaktır. Öyleyse, biz şimdi göğün on iki burcu ve on iki ay sayısı kadar her yıla birer ad koyalım; sağışlarımızı bu yılların geçmesiyle anlayalım. Bu, unutulmaz bir yadigâr olarak kalsın" dedi. Ulus, hakanın bu önerisini onayladı. Bunun üzerine hakan ava çıkar ve yaban hayvanlarını büyük bir ırmak olan Ilısu’ya doğru sürmelerini 
emreder. Halk bu hayvanları sıkıştırarak suya doğru sürer. Hayvanların bir kısmı suya düşerken, on iki tanesi ise suyu geçer. Her geçen hayvanın adı bir yıla ad olarak verilir. Irmağı geçen ilk hayvan sıçan olduğu için senenin başı bu hayvanın adıyla anılmıştır (Atalay 1992: 344-345).

\section{Başkurtlarda On İki Hayvanlı Takvim}

Başkurtlar arasında on iki hayvanlı takvimle ilgili bir rivayet bulunmaktadır. $\mathrm{Bu}$ rivayete göre bir zamanlar on iki tane hayvan bir araya toplanarak yıl hesabını takvimlendirmek istemişler ve her yıla bir hayvanın ismini koymaya karar vermişler. Böylece, "müsel" denilen on iki hayvan isminden oluşan takvim ortaya çıkmıştır. Ancak her hayvan bu takvimin başında kendi isminin olmasını isteyince, "Kim güneşin doğuşunu ilk görürse, onun adı birinci sırada olacak" denmiş. Tanın ağarmasını beklemeye başlamışlar. Sığır, kendisinin diğer hayvanlara göre daha uzun boylu olduğunu bildiğinden takvimin başında kendisinin olacağını düşünmüş. Ancak, sıçan gizlice onun boynuzuna çıkınca güneşin doğuşunu ilk olarak o görmüş. Bundan dolayı takvimin ilk yllına onun ismi verilmiştir (Süleymenov vd. 1995: 174-175).

Yılların hangi hayvan yılı olacağı ve o yılda nelerin gerçekleşeceğine dair yorumlar da yapılmıştır. Örneğin; "1912 yılına Sıçan Yılı denk gelirse o yıl kutsal olacaktır. Daha sakin ve bol yağmurlu olacaktır. Bu yılda doğan çocuk zeki olacaktır" yorumu Sterlitamak Devlet Pedagoji Enstitüsü Başkurt Dili ve Edebiyatı Bölümü arşivindeki tahminen XIX. yüzyıl sonlarında istinsah edilmiş bir elyazma belgede göze çarpmaktadır.

Divanü Lügati't-Türk'te, "Türkler bu yılların her birinde bir hikmet olduğunu sanarak o yılla ilgili fal açıp onu uğur sayarlar.” denilmiştir. Örneğin, "Ud (Öküz) yılına girildiğinde savaş çoğalırmış. Çünkü öküzler birbirleriyle vuruşur, toslaşırlarmış. Tavuk yılında yiyecek çok olur, ancak insanlar arasında karışıklık çıkarmış. Çünkü tavuğun yemi tanedir. Tavuk, taneyi bulabilmek için çöp ve kırıntıların içini karıştırır. Timsah yılı girdiğinde yağmur çok yağar, bolluk olurmuş. Çünkü timsah suda yaşar. Domuz yılı girince kar ve soğuk olur, kargaşa çıkarmış" (Atalay 1992: 347).

Kaşgarlı Mahmut, kendi eserini yazdığı zamanı örnek alarak şöyle demektedir: "Biz, şu kitabı yazdığımızda dört yüz altı senesinin Muharrem ayı idi; yılan yılı girmişti. Bu yıl geçip de 467 yılı olunca at yılı girecektir" (Atalay 1992: 346). 


\section{Türklerde Yılbaşı}

Başkurtlar arasında kullanılan Türk takviminin bir çeşidi 1935 yılında Başkurdistan’ın Gafuri ilçesi İbrahim köyünde Abdulla Sadıkov tarafından Arap harfleri ile yazılan bir el yazmadan istinsah edilmiştir (Sadıkov 1935). Bu yazının baş kısmında yılbaşının mart ayında olduğu bildirilmiştir. Türklerde yılbaşının mart ayında olduğunu buradan da anlıyoruz.

Bilindiği gibi, 21 Mart On İki Hayvanlı Türk Takviminden hariç Selçuklu Hükümdarı Sultan Melikşah’a (1055-1092) izafeten yapılan ve Celâliye (Tarih-i Celâli, Tarih-i Melik'i) ismindeki takvimde de yllbaşı olarak geçmektedir (Yazıcı Ersoy 2007: 260).

Saha araştırmalarının bilgilerine göre çok eskiden başlayıp XX. yüzyılın ikinci yarısına kadar devam eden, hatta günümüzde de bazı bölgelerde devam etmekte olan bayram kutlamaları mevcuttur ve bu kutlamalar mart ayında, hayvanların kellesinden yapılan yemekler yenilerek yapılmaktadır. Sonbaharda kesilen hayvanların kelleleri bu bayramda kullanılmak üzere saklanmıştır. Yani kelle, yılbaşı kutlamalarının bir yemeği olmuştur (Salihov 1992, Salihova 1992).

Diğer taraftan ise, halk edebiyatını inceleyen bilim adamlarının verdiği bilgilerine göre, Nevruz'da dövülmüş buğdaydan yapılmış bir yemek de hazırlanmaktadır (Süleymenov, Soltangereyeva 1995: 191).

Prof. Dr. Tuncer Baykara tarafından Kazakistan ve Altaylarda yaşayan Kazakların Türk takvimlerindeki ay adlarının az kullanılmasından dolayı biraz kaymış olduğu belirlenmiştir (Baykara 2001: 39). Diğer taraftan Kazakistan Kazaklarında günümüzde kullanılan takvime göre yılın son ayının Celtoksan olarak adlandırıldığ bilinmektedir. Başkurtçada eski takvimin son ayının ismi Yıltukhan'dır. Dedelerimizin anlattı̆̆ına göre Yıltukhan ayı, Mart ayı (yılbaşı bayramı) dönemine gelmektedir. Yine, Kazak folklor araştırmacısı Aksar Turganbayev' in verdiği bilgiye göre Kazaklarda önce Celtoksan, sonra Ortatoksan ve arkasından Ayaktoksan ayı gelmekteydi. Ay isimlerindeki bu karışıklık nedeniyle Prof. Dr. Tuncer Baykara’nın dediği gibi Türk takvimi konusu yeniden ele alınmalıdır. 


\section{Başkurtlarda Nevruz’un Bazı Özellikleri}

İlkbaharın başlamasıyla ilgili olarak Başkurtlarda çeşitli bayramlar vardır. Bu bayramlar doğanın kutsal kabul edilmesiyle ilgilidir. Karga Butkahı (Karga Lapası), Kekük Seyi (Guguk Çayı) gibi bayramlar Türklerin doğanın bir parçası olan kuşları kutsal kabul etmesiyle ilgilidir.

X. asırda Arap bilginlerinden İbn Faldan, Başkurtların kış, yaz, yağmur, rüzgâr, ağaç (orman), hayvan, insan, su, gece, gündüz, ölüm, hayat ve yer gibi on iki tabiat ruhuna inandıklarını, en büyük tanrının da gökte yaşadığını varsaydıklarını kaydetmiştir (İnan 1972: 27).

Doğayı kutsal kabul eden Başkurtlar ilkbaharda, Mayıs ayında günler ısınınca Karga Butkahı adlı bir bayram icra etmektedir. Çünkü Türkler göçmen kuşları tabiatın uyanışının ve kötülük tanrısının yenildiğinin habercisi olarak kabul etmektedir (Oğuz 2011: 114). Karga, sığırcık gibi kuşlar, Başkurdistan’a ilkbaharda gelmeye başlar. Karga ve sığırcık ilk gelen göçmen kuşlardandır. Başkurtlar buna dikkat ederler. Marttaki en kuvvetli son tipinin ismi szyırsık buranı, yani sı̆̆ırcık tipisi olarak adlandırılmaktadır. Başkurtlar bu tipinin başlamasının ilkbaharda güneydeki sıcak memleketlerden gelen sığırcıkların kanatlarını çırparken oluşturdukları rüzgârdan kaynaklandığına inanmaktadırlar (Salihova 2009).

Eskiden Başkurtlar arasında dilekçiler (теләкселәр) olarak adlandırılan bir gelenek olduğunu tespit eden Kirey Mergen, Nevruz dönemindeki dilekçilerin Nevruzcular (наурузсылар) şeklinde özel adlandırıldıklarına dikkat çekmektedir. Ona göre, nevruzcular geleneği tamamen mevsim bayramı ile alâkalıdır. Onlar halk arasında gezerek dinî rivayetler bazen doğu halk edebiyatından alınmış hikâyeler anlatmışlar bazen de münacatlar söylemişlerdir. İdil-Ural bölgesinde en yaygın folklor eseri olarak bilinen beyitlerin bir kısmı nevruz adını taşımaktadır. Basılmış kitap ve elyazma şeklinde yayınların bazıları "Nevruz Kitapları", "Nevruz Beyetleri”, Kıssa-i Nevruz" olarak adlandırılmıştır (Mergen 1961: 83-87).

Nevruzcular sadece Ufa, Orenburg civarında değil, Kazan taraflarında da görülmüştür. Tanınmış bilgin Şehabettin Mercani'nin "Müstafadel-ahbar" kitabındaki bilgilere göre, Kazan yanındaki Memse köyünde nevruzcular ile birlikte köyün imamı da buğday toplamıştır (Mergen 1961: 85-86). 
Nevruz kutlamalarında çeşitli şiirler söylenmektedir Bu şiirlerde yılın iyi olması ve buğdayların iyi yetişmesi temenni edilir. Nevruzdaki şiirlerden biri şu şekildedir:

\section{Başkurtçası:}

Navruz yılga baş bulır,

Boyzay aşka baş bulır,

Boyzay ưha aş bulır,

Uymaha taş aş bulır.

Yıldın başı uך bulhın,

Rizıgı mul bulhın,

İendere şaşıp ūhın,

Kazandar taşıp torhon

Bir könderzen hilen

Ilder bulhın imen.

\section{Türkiye Türkçesi:}

Nevruz yıla baş olur,

Buğday aşa başolur,

Buğday yetişirse aş olur,

Yetişmezse taş aş olur.

Yılın başı iyi olsun,

Rızıkları bol olsun,

Buğdaylarl iyi yetişsin,

Kazanlar taşıp dursun

Ver sakin günleri

Iller olsun aman (Süleymanov 2000: 32-33).

Nevruzda geleneksel kıyafetler giyen insanlar birbirini ziyaret etmişlerdir. Nevruz günü gençler ve çocuklar, yaşlıların hâllerini sormuşlardır. Büyükleri ziyaret etmenin önemi ile ilgili olarak Nevruz'da söylenen şiirlerden biri de şudur:

\section{Başkurtçası:}

Navruzda kem karttarzın

Helen belmey,

Şul keşenen işegene

Iris inmey.

Navruzda onotkandin

Ololarzl

Eşkinmeyse, uyga-hulga

Orolgani...
Türkiye Türkçesi:

Nevruzda kim ihtiyarlarl

Ziyaret etmez,

O insanın kapisindan

Saadet girmez.

Nevruzda unutanın

Büyükleri

İşe yaramadan, săga-sola

Vurulmuştur... (Süleymanov 2000: 38-39).

Nevruzda çeşitli geleneksel halk oyunları da oynanır. Başkurt folklor araştırmacılarının tespitlerine göre, Nevruz bayramında at koşturma 
(ат сабыштырыу), güres (көрәш), kız kovalama (кыз̧ кыуыу), birbirini çekme (тартышыу) gibi çeşitli oyunlar oynanmaktadır. Kutlamalar Nevruz ayı olan Mart boyunca devam etmiştir. Bu oyunlar Sabantoy zamanında da yapılmıştır (Süleymenov 1995: 191, 228-240).

Bununla birlikte Başkurdistan'da Nevruz'un hava durumu açısından güneyde yaşayan diğer Türklere göre karın bulunduğu bir zamanda olduğu dikkate alınmalıdır. Sabantoy ise bahar gelince, tarlalar sürülüp ekinler ekildikten sonra yapılmaktadır.

Sabantoy bayramı günümüzde bütün köylerde ve şehirlerde kutlanmaktadır. Bu bayramda yapılan "Bakan" denilen direğe tırmanma oyunu gibi bazı oyunlar eski Türk inançlarından gelmektedir. Bu bayramın da Nevruz’u andıran tarafları mevcuttur. Her iki bayram da baharda yapılır, bol bol millî yemekler hazırlanır, o yılki hasadın iyi olması dilenir.

Türkiye’deki araştırmalara göre, Başkurtlardaki Sabantoy bayramında yapılan oyunlarla diğer Türk halklarında Nevruz kutlamalarındaki oyunlar benzerlik göstermektedir (Yazıcı Ersoy 2007: 261, Oğuz 2000: 435-436).

Başkurdistan’ın Belaret ilçesi Zöyek köyünde kışı uğurlama bayramı günümüzde de yapılmaktadır. Bu bayrama hem çocuklar hem de yaşlılar katılır. Nineler ayaklarına çuval giyerek koşar; dedeler ise kızakla yarışır (Süleymenov 1995: 191-192).

İnsanlar, Nevruz sırasında Nevruzbike olarak seçtikleri kıza sordukları soruların cevabına göre yılın nasıl olacağını yorumlamışlardır (Süleymenov 1995: 191-192).

Edebiyatta Nevruzla ilgili beyitler, hamaklar (maniler), tekerlemeler yer almaktadır. Bazıları sadece bayram havasına eğlence katmak, bazılarıysa ifade etmek istenen duyguların düşüncelerin bildirilmesi içindir. Bu tür şiirlerin örneklerinden biri de şöyledir:

Başkurtçası:

Gözör hüzem şul hezge

Kizınd bir hin bezge

Savap bulır ul hezge

Navruz bulhın möberek!

\section{Türkiye Türkçesi:}

Rica sözüm şu size

Kızınızı verin bize

Sevap olur o size

Nevruz olsun mübarek! (Süleymanov 2000: 29). 


\section{Nevruzun Türk Kültüründeki Yansımaları}

Bahar gelince doğa yeşillenir. Nevruz da bununla bağlantılıdır. Türk halkındaki Hızır kelimesi, Arapçada yeşil anlamına gelmektedir (Oğuz 2001: 114). Hızır miti, Başkurtlarda da çok yaygındır. Eskiden her köyde anlatılan bu mit zamanla her köyde ayrı bir rivayet hâline gelmiştir.

Nevruz Bayramının ortaya çıkışı Ergenekon Destanı'na da bağlanmaktadır (Kırzıoğlu 1995: 309-314). Türkiye'de yapılan Nevruz Bayramında Ergenekon'dan çıkış demir dövme geleneğiyle anlatılır. Başkurtlarda Ergenekon Destanı eski zamanlarda yaygınken bugün unutulmuştur. XIX. asrın sonu XX. asın başında yaşayan Başkurt bilim adamlarından Garifulla Kiyikov'un Başkurt tarihine ait elyazmasında bu rivayete yer verilmiştir. Bu elyazmada Ergenekon ormanındaki dar bir yoldan dağlar arasına gelip yerleşen Başkurtlardan ve o dağın da Ural dağları olabileceğinden bahsedilmiştir (Kiyikov, $\mathrm{XX}$. asrın başı: 1).

Türk halklarında ateş de kutsal sayılmaktadır. VI. yüzyılda Türkler, Göktürk kağanına gelen Bizans elçilerini önce iki ateşin arasından geçirmişlerdir (Arslan 1995: 251-272). Nevruz kutlamalarında ateş üzerinden atlama geleneği de vardır. Bu gelenek Başkurtlarda bugün unutulmuştur. Ancak ateşin kutsallığ ile ilgili birçok inanç korunmuştur. Eski zamanlarda hastalıklardan ve afetlerden korunmak için Başkurtlar Sıgır Utı, yani yeni ateş yakma merasimi yapmışlardır (Nagaeva 1981). Kügersen ilçesi, Bikeş Köyü’nde bu merasimin XX. yüzyılın başlarına kadar yapıldığı hatırlanmaktadır. Sıgır Utı (yeni ateş) tüm köyün ateşi söndürüldükten sonra iki ağacın birbirine sürtülerek ateş yakılmasıdır. Bütün köy halkı, kendi ocağına bu ateşten alırmış, insanlar yakılan ateşin arasından geçermiş (Salihov, Gübey 1992). Buna benzer bir gelenek Kuzey ve Güney Amerika’da yaşayan Kızılderililer tarafından da uygulanmaktadır. Aztek Kızılderililerinde en büyük dinî merasim sayılan bu gelenek "Toxıuhmolpilia" (Ateşin Yenilenmesi) adını almaktadır. Aztekler bu merasimi her elli iki yılda bir Yıldızlar Tepesi'nde yaparlarmış. Ülkedeki tüm ateşler söndürülür, ateş saklanan çömlekler kırılır, önemli savaş esirleri kurban edilir, orada ateş yakılır ve mabetler üzerinden tüm ülkeye dağıtılırmış. Aztekler, böylece herkesin sağlıklı olacağına inanmışlardır (Hinnels 1984, Arslan 1995: 265). Meşhur Kırım Tatar aydınlarından İsmail Gaspralı tarafından yayınlatılan Tercüman gazetesinde 1903 yılında yayınlanmış yazıya göre, Doğu Türkistan'daki Külce şehrinde buralarda yaşayan halkların tümü müslüman olmalarına rağmen yıl- 
da bir kez genci ihtiyarı, kadını erkeği herkes şehir meydanları ve sokaklarında kötülüklerden arınmak için ateş yakarak üzerinden atlamışlardır. Müellif bu gelenekle ilgili imamlar kendileri katılmadığı hâlde halkın yaptıklarını yasaklamamışlar demiştir (Tercüman 1903).

Fakat birkaç ay sonra Muhammed Nasır Semerkandi adlı birisi aynı gazetede itiraz yazısı yayınlatmıştır. Ona göre, önceki haberin müellifini çocukların ateşle oyunları yanıltmıştır. M. N. Semerkandi bu taraflarda böyle bir geleneğin olmadığını vurgulamıştır (Semerkandi 1903). Ancak o bölgede yaşayan Uygur Türkleri arasında bugünlerde de düğün gelenekleri arasında yeni evlenen çiftin ateş etrafında dolaşması mevcuttur. Bu gelenek diğer göçebeler arasında eskiden gelinin damat evine gelişinden sonra eve girmesinden evvel üç kere ateş etrafinda dolaşmasından gelmektedir (Reşetov 2000: 567-568).

Ateş ve ocak Tüklerde kutsal sayılmıştır. Yılbaşında, gerektiği durumlarda hastalık ve kötülüklerden arınmak, yeni hayat başlatmak için ateş üzerinden ve arasından geçmişlerdir.

\section{Sonuç}

Eskiden diğer Türk halklarındaki gibi Başkurtlarda da eski takvime göre yılbaşı bayramı olarak Nevruz en önemli bayramların biri olmuştur. Nevruz Bayramı eski on iki hayvanlı Türk takvimine göre Mart ayında gerçekleştirilmiştir. Başkurt folklorunda da bu bayram için söylenen çeşitli şiirler bulunmaktadır. Bu şiirlerde Nevruz bayramı sırasında insanlar birbirlerine yılın iyi olmasını, buğdayların iyi yetişmesini dilemişlerdir. Halk edebiyatı örnekleri bayramın nasıl geçtiğini de göstermektedir. Başkurtlarda Nevruz bayramının ekin ekildikten sonra yapılan Sabantoy bayramına benzeyen bazı tarafları bulunmaktadır. Her iki bayram da baharda yapılır, bol bol millî yemekler hazırlanır, o yılki hasadın iyi olması dilenir. Bahar gelince doğa yeşillenir. Nevruz da bununla bağlantılıdır. Türk boylarındaki Hızır kelimesi, Arapçada yeşil anlamına gelmektedir. Hızır miti, Başkurtlarda da çok yaygındır. Bu konu ise kendisi ayrı bir araştırma konusu niteliğindedir. Nevruzda çeşitli geleneksel halk oyunları oynamışlar, bayram sırasında yılın nasıl olacağını yorumlamışlardır.

Sabantoy ve onun yerel çeşitleri olan Yıyınlara nazaran kaynaklarda Başkurtlar arsında kutlanılan Nevruz hakkında bilgiler daha azdır. Sovyet döneminde 1921 yılından itibaren Sabantoy bayramı spor ve emek bayramı olarak resmî olarak da kutlanmıştır (Salihov 2015: 348). Nevruz, Nevruzculuk dinî bir 
gelenek olarak değerlendirilmektedir (Mergen 1961: 83-87). Bu durum, Başkurtlar arasında Nevruz bayramının Sovyet döneminde ortadan kaldırılmasının da sebebidir.

Bugün, Başkurdistan Kültür Bakanlığının destekleri ile Nevruz Bayramı yeniden kutlanmaya başlanmıştır. Nevruz Bayramı Ufảnın en güzel meydanlarından biri olan millî kahraman Salavat Yulayev heykeli yanındaki gibi büyük meydanlarda kutlanmaktadır (Galiullina, Yeşlek Gazetesi, 25.03. 2003).

Başkurtlarla birlikte Nevruz Bayramını, Başkurdistan'da yaşayan diğer Türk boyları ile Müslüman halklar da kutlamaktadırlar. Başkurtlar, Tatarlar, Özbekler, Kazaklar, Azerbaycanlılar, Türkmenler, Tacikler, Çeçenler, Dağıstanlılar kurdukları çadırlarda sergiler düzenlerler. Bu halkların temsilcileri kendi millî yemeklerini yaparak çeşitli oyunlar ve türkülerle kendilerini tanıtmaya çalışırlar ve birbirleriyle bayramlaşırlar. Bayram programında şarkıcıların yarışması dikkat çeken bir etkinliktir. Ayrıca millî yemeklerin hazırlanmasına da çok önem verilmektedir. İnsanlar bu yemeklerden tadarlar ve eğlenceli bir gün geçirirler. Son yıllardaki ortak kutlamalarla Nevruz Bayramı bir hoşgörü ve dostluk bayramı geleneğine dönüşmüş olsa da Sabantoy kadar geniş çapta kutlanılmamaktadır.

Bu makalede Nevruz hakkındaki araştırma ve bilgiler bir araya getirilerek Nevruz'un Başkurt kültüründeki yeri tespit edilmeye çalışılmıştır.

\section{Kaynaklar}

Arslan, Ahmet Ali (1995). "Amerika Kızılderili Kabileleri ve Türk Dünyasında "Yeni Yılbaşı” Merasimlerinde Paralellikler”. Türk Kültüründe Nevruz Uluslararası Bilgi Şöleni (Sempozyumu) Bildirileri (Ankara, 20-22 Mart). Ankara: AKM Yay.

Atalay, Besim (1992). Kasgarl Mahmut, Divanü Lügat-it Türk Tercümesi. I. Cilt. Ankara: TDK Yay.

Baykara, Tuncer (2001). “Türk Takvimi: On İki Hayvanlı Türk Takvimi ve Yılın Başlangıcı”. Türk Kültürründe Nevruz Dördüncü Uluslararası Bilgi Şöleni Bildirileri (2123 Mart, Sivas). Ankara: AKM Yay.

Valişin, Rifkat vd. (2011). Yazıki i Narodı Respubliki Başkortostan. Gosudarstvennuye Yazıki: İstoriya i Sovremennost. Sbornik Dokumentov i Materialov. Ç. 3. Realizatsiya Gosudarstvennıh Yazıkov v Oblasti Kulturı i İskusstva / Sost. A.A. Abuzarov, R.A. Valişin (otvetstvenniy), A.G. Karimov, Yu. H. Yuldaşbayev. Ufa: GUP RB UPK. 
(Языки и народы республики Башкортостан. Государственные языки: история и современность. Сборник документов и материалов. Ч. 3. Реализация государственных языков в области культуры и искусства / сост. А.А. Абузаров, Р.А. Валишин (ответственный), А.Г. Каримов, Ю.Х. Юлдашбаев. Уфа: ГУП РБ УПК, 2011).

Galiullina, M. (2003). "Nauruz Tuganlık Histeren Nıgıttı”. Yeşlek (Gazete). 25.03.2003. (Ғәлиуллина М. “Наурыз туғанлык хистәрен нығытты”. Йәилек. 25.03.2003).

İnan, Abdülkadir (1972). Tarihte ve Bugün Şamanizm Materyaller ve Araştırmalar. Ankara: TTK Yay.

Kırzıoğlu, Neriman (1995). “Eski Türklerin Ergenekon'dan Çıkış Bayramı / Sultan Nevruz (21 Mart)”. Türk Kültüründe Nevruz Uluslararası Bilgi Şöleni (Sempozyumu) Bildirileri (Ankara, 20-22 Mart). Ankara: AKM Yay.

Kiyikov, Garifulla (XX asr başı). Başkort Tarihı. Fond Rukopisey i Staropeçatnıh Knig Ordena Znak Poçeta İnstituta İstorii, Yazıka i Literaturı Ufimskogo Federalnogo İssledovatelskogo Tsentra Rossiyskoy Akademii Nauk. A 78-3. (Кейеков, Ғәрифулла. (XX быуат башы). Башкорт тарихы. Фонд рукописей и старопечатных книг Ордена Знак Почета Института истории языка и литературы Уфимского федерального исследовательского центра Российской академии наук. А 78-3).

Mergen, Kirey (1961). Başkort halkının Epik Komartkıları. Ufa: Başkortostan Kitap neşriyeti (Мәргән, Кирәй (1961). Башкорт халкының эпик комарткылары. Өфө: Башкортостан китап нәшриәте).

Nagaeva, L.İ. (1981). Tantsı Vostoçnıh Başkir. Moskova: Nauka, 1981. (Нагаева Л.И., Танцы восточных башкир. М.: Наука, 1991).

Oğuz, Öcal (2000). "Başkurt Geleneksel Şölenlerine Genel Bir Bakış ve Habantuy”. Dördüncü Türk Kültürü kongresi Bildirileri. 4-7 Kasım 1997. Ankara.

Oğuz, Öcal (2001). “Türklerde Hızır Kavramı”. Türk Kültüründe Nevruz Dördüncü Uluslararası Bilgi Şöleni Bildirileri (21-23 Mart, Sivas). Ankara: AKM Yay.

Reşetov A. M. (2000). Uygurı, Narodı i Religii Mira. Ensiklopediya. Moskva. (Решетов А.М. Народы и религии мира. Энциклопедия. М., 2000). Sadıkov, Abdulla (1935). Türki Yıl Hesabı.1935 yılına ait Arap harfleriyle İdil-Ural Türkçesiyle yazılmış elyazma. 
Salihov, A.G. (2015). Başkirskiy Sabantuy v Pismennıh Dokumentah. XI Kongress Antropologov i Etnografov. 2-5 iyulya 2015 g. Yekaterinburg. 2015 (Салихов А.Г. Башкирский Сабантуй в письменных документах. XI Конгресс антропологов и этнографов. 2-5 июля 2015 г. Екатеринбург. 2015).

Semerkandi, Muhammed Nasır (1903). “O Tarançintsakh”. Tercüman (Gazete). 23.06.1903. (Самарканда, Магомед Насыр, О таранчинцах. Терджиман. 23.06.1903).

Süleymanov, Ahmet (1995). "Başkurt Halkının Milli Bayramlar Sisteminde Nevruz". Uluslararası Bilgi Şöleni Bildirileri, 20-22 Mart. Ankara.

Süleymanov, Ahmet (2000). "Başkurtlar”. Türk Dünyası Nevruz Şiirleri Antolojisi. Ankara: AKM Yay.

Süleymanov, Ahmet ve R. Soltangereyeva (1995). Başkort Halık Ijadı. 1 Tom: Yola Folklorı. Ufa: Кitap (Сөләймәнов Ә. һәм Солтангәрәева Р. (1995). Башкорт хальк ижадыл. 1 том: Йола фольклорыл. Өфө: Китап).

Tacettin bin Yalçıgul (1908). Risalei Azize şerhi Sabatel Acizin. Kazan: Matbaa-1 Kerimiye (Тажетдин бин Ялчығол. (1908). Рисаләи Ғәзизә шәрхе съәбат әлzажизин. Казан: Матбаға-и Кәримиә).

Tercüman (1903). "Razniye Vesti”. Tercüman (Gazete). 03.01.1903.

Tuhvatullin, M. (1990). “Nauruz-Bahar Bayramı”. Başkortostan (Gazete). 21.04.1990 (Төхвәтуллин М. “Наурыз - яз байрамы”, Башкортостан, 21.04.1990).

Turan, Osman (2004). On İki Hayvanl Türk Takvimi. İstanbul: Ötüken Yay.

Yazıcı Ersoy, Habibe (2007). "Başkurt Türklerinde Nevruz". Türk Dünyası Nevruz Ansiklopedisi. Ed. Öcal Oğuz. 259-268.

\section{Kaynak Kişiler}

Salihov, Gübey (1992). Rusya Federasyonu - Başkurdistan Cumhuriyeti, Kügersen İlçesi, Bikeş Köyü. 1932 doğumlu, okuma yazma biliyor, mekanizatör (emekli), 1992 yilında derlenmiştir.

Salihova, Gülbike (1992, 2009). Rusya Federasyonu - Başkurdistan Cumhuriyeti, Kügersen İlçesi, Bikeş Köyü. 1935 doğumlu, okuma yazma biliyor, satış elemanı (emekli), 1992, 2009 yıllarında derlenmiştir. 


\title{
Ancient Turkic Calendar and the Celebration of Navruz by the Bashkirs*
}

\author{
Akhat Salikhov $^{* *}$
}

\begin{abstract}
In earlier days, as in other Turkic places Bashkir folk festival of Navruz held annually according to the old oriental calendar, has been one of the crucial holidays. The Navruz Day used to be held in March, according to the Turkic peoples ancient calendar. The Bashkir folklore preserved the poetic works that are used on this holiday. They contain suggestions for good harvest and other good wishes, who wanted people to each other. Samples of folk art is also shown holding the holiday. Some of Navruz holiday party Bashkirs have similarities with the celebration of Sabantuy, which are carried out after the end of the planting season. During both events were carried out folk games, preparing national dishes, talking about the wishes of a good harvest.

This feast for various reasons has been kept in oblivion in the past century which now has become a part of our culture. Since 1990 Navruz began to be celebrated again in Bashkortostan. Despite this, Navruz is not so marked in comparison with Sabantuy.

\section{Key Words}

Turkic Culture, Navruz, the twelve animals cycle of the Turkic calendar, Bashkirs, national holidays.
\end{abstract}

Date of Arrival: 07 November 2016 - Date of Acceptance: 23 May 2018

You can refer to this article as follows:

Salihov, Ahat (2019). "Başkurtlarda Eski Türk Takvimi ve Nevruz Bayramının Kutlanması”. bilig - Türk Dünyası Sosyal Bilimler Dergisi 88: 189-203.

** Ph.D., Order of the Badge of Honour Institute of History, Language and literature - Subdivision of the Ufa Federal Research Centre of the Russian Academy of Sciences, Department of Oriental Sciences - Ufa/Russian

ORCID ID: https://orcid.org/0000-0002-7994-4711

ahatsalihov@mail.ru 


\title{
Тюркский календарь и празднование Навруза у башкир*
}

\section{Ахат Салихов ${ }^{* *}$}

\begin{abstract}
Аннотация
В прошлом башкиры, как и многие другие тюркские народы, праздновали Навруз - начало нового года по восточному календарю. Он был одним из важных народных праздников, который проводился в марте месяце в день весеннего равноденствия. В башкирском фольклоре сохранились поэтические произведения, посвященные этому празднику. В них содержатся добрые пожелания друг другу, пожелания хорошего урожая. Образцы народного творчества отражают особенности проведения данного праздника у башкир. Проведение Навруза у башкир имеет некоторое сходство с празднованием Сабантуя, который проводится после окончания посевных работ. Во время обоих мероприятий проводили народные игры, готовили национальные блюда, звучали пожелания хорошего урожая. Празднование Навруза связано с наступлением весны, когда природа начинает пробуждаться. В этот день состоялись различные традиционные церемонии, Одним из которых было предсказание о предстоящем годе.

Начиная с 1990 годов праздник Навруз, по определенным причинам ушедший в забвение в прошлом веке, вновь становится частью культурной жизни башкир. Несмотря на это, по сравнению с Сабантуем он отмечается не так широко.
\end{abstract}

\section{Ключевые слова}

Тюркская культура, Навруз, двенадцатилетний животный тюркский календарь, башкиры, народные праздники.

\footnotetext{
* Поступило в редакцию: 7 ноябрь 2016 г. - Принято в номер: 23 май 2018 г.

Ссылка на статью:

Salihov, Ahat (2019). "Başkurtlarda Eski Türk Takvimi ve Nevruz Bayramının Kutlanması". bilig - Türk Dünyası Sosyal Bilimler Dergisi 88: 189-203.

** Кандидат исторических наук, Институт истории, языка и литературы Уфимского федерального исследовательского центра Российской академии наук, отдел восточных рукописей - Уфа/ Россия ORCID ID: https://orcid.org/0000-0002-7994-4711 ahatsalihov@mail.ru
} 
